\title{
Reliability and maintainability of scraper conveyor used in coal mining in the Jiu Valley
}

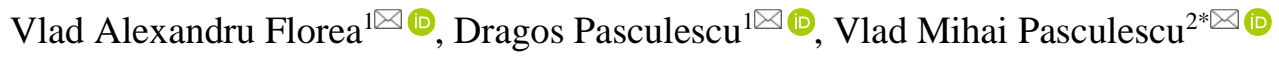 \\ ${ }^{1}$ University of Petrosani, Petrosani, 332006, Romania \\ ${ }^{2}$ National Institute for Research and Development in Mine Safety and Protection to Explosion - INSEMEX, Petrosani, 332047, Romania \\ *Corresponding author: e-mail vlad.pasculescu@insemex.ro, tel. +40765616288
}

\begin{abstract}
Purpose. The aim of the study is to determine and analyse causes of faults in the operation of TR-7A scraper conveyor and to estimate the required time for their remediation and select the methods of their prevention and elimination.

Methods. The characteristic of a system, such as the scraper conveyor, intended to fulfil its specified function in time and operation conditions, can be studied, theoretically, by determining its operational reliability. This implies the existence of a framework that incorporates several interconnected components of technical, operational, commercial and management nature. The quantitative expression of reliability was based on elements of mathematical probability theory and statistics (exponential distribution law), failure and repair mechanism not being subject to certain laws.

Findings. The following TR-7A subassemblies, if defective, could have been the cause of a failure: chains, hydraulic couplings, chain lifters, drive, return drums, some electrical equipment. After 28 months of monitoring the TR-7A operation, we have established the number of failures (defects) $n_{i}$, the operating time between failures $t_{i}$, frequency of failures $f_{c}$, time to repair $t_{r i}$, weight repair time $p_{r}$, mean time between failures (MTBF), mean time to repair (MTR).

Originality. Data collection and processing involves the adoption of specific procedures to allow the correct highlighting of the causes and frequency of failures. The accomplishment of this approach allowed finding the solutions for increasing reliability of some subassemblies of TR-7A conveyor (i.e., those subjected to abrasive wear).

Practical implications. One solution was to use materials with compositional and functional gradient in the case of worn surfaces of some subassemblies. It was successfully applied for the chain lifters where a significant increase in the mean time between failures was obtained. The field of application of these materials can be extended to the metal subassemblies of machines and equipment with abrasion wear that occurs both in underground mines and in quarries.
\end{abstract}

Keywords: conveyor, exponential distribution law, multilayer structure, recondition, reliability, wear

\section{Introduction}

All over the world, researchers and engineers who are concerned about improving underground or surface mining processes constantly deal with various tasks aimed at enhancing reliability of technical equipment to optimize its operation, and thus increase productivity. Belt and scraper conveyers play an important role during mining operations, their safe and reliable operation being a mandatory condition for the proper extraction of mined minerals.

Conveyers are considered a critical component of modern coal mining transportation system; therefore, it is essential to diagnose and monitor their damage accurately. Recent trends in this regard have led to the development of Adaptive Deep Convolutional Network methods which can better meet the real-time and reliability requirements of conveyor belt damage detection [1].
Also, high processing computing has led to an extensive use of numerical models for analysing the behaviour of mining equipment in operation and for characterizing their dynamics under various conditions [2]. By analysing simulation results, critical components can be ranked, and reliability-based preventive maintenance schedules for all mining equipment concerned can be developed [3].

The conveyor, the most important subsystem in a mining scraper, is a highly coupled, chain drive system which has been analysed based on dynamic meshing properties. Such studies were carried out to improve reliability of scraper conveyors, while the contact analysis of the chain drive system was simulated using state-of-the-art finite elements analysis software. Contact analysis based on meshing properties is useful in describing the dynamic properties of the chain drive system in detail [4]. 
Romanian scientists are also concerned about reliability and maintainability issues of mining equipment. They have conducted extensive research into reliability of conveyor belts in underground coal mines in the Jiu Valley and discovered that the transportation system was responsible for many downtimes because of the poor state of belt conveyers [5].

In Romania, there has been a decreasing trend of coal consumption, which led to $19 \%$ drop of primary energy consumption, in 2016, the equivalent of $62.8 \mathrm{TWh}$ decrease, which, compared to 2011 , came up to $26.4 \%$. In the future, it is expected that the Vulcan and Livezeni mines will remain functional until 2030, without taking into account investments in their technical upgrade, so one must look for solutions to rehabilitate the existing technological equipment [6]-[8].

Coal mining machines and equipment are subject to varying loads in a polluted and aggressive environment where their working surfaces suffer various forms of wear, of which abrasion is common and produces negative effect that eventually results in numerous interruptions in operation. Hence, there is an increase in the consumption of spare parts, which involves high expenses [9], [10].

The decision to reduce coal production in the Jiu Valley has influenced the technical and economic indices of recent years. It has also affected the use of mechanized complexes CMA-2 and their components, including the TR-7A conveyor (Fig. 1), by exceeding the cycle of 4-year operation without strict observance of maintenance activities.
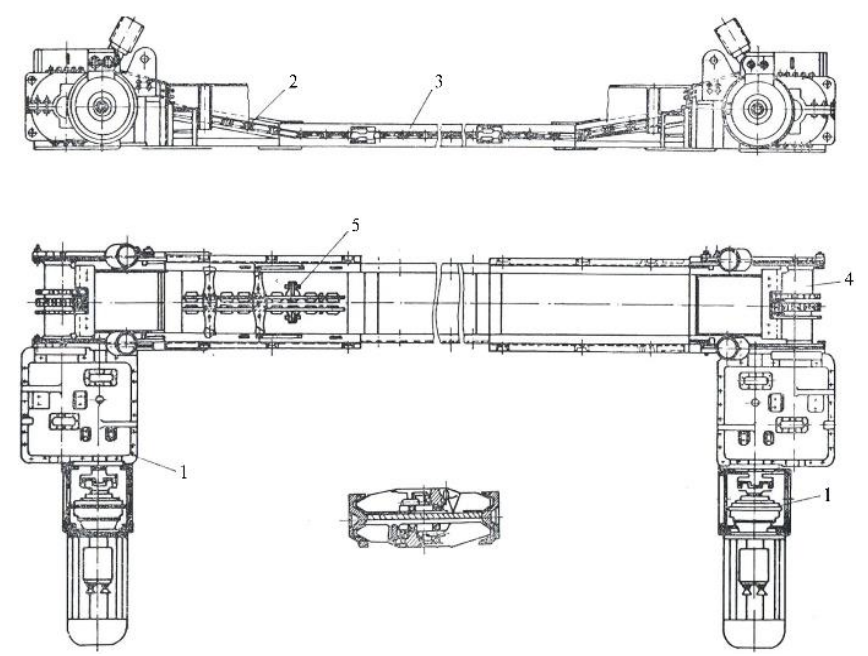

Figure 1. TR-7A scraper conveyor: 1 -drive station composed of electric motor, hydraulic coupling and reducer; 2 - intermediate trough; 3 -trough column; 4-return head; 5 - scraper and transport chains

In the specialized literature, the authors focus their analysis, in most cases statistically, on the production losses arising due to the defects, without indicating the adequate solutions to the problems [11], [12].

Although considerable progress has been made in increasing the service life of subassemblies and spare parts of mining equipment; it has not, however, led to an equivalent increase in the service life of the equipment itself. Thus, we face a paradoxical situation when the machines have a shorter lifespan than their components. Consequently, it is necessary to analyse the quality of service life of the equipment and its components operating under specific operating conditions, in order to establish ways to increase their reliability $[13,14]$.
The objective of the current research is to determine and analyse the causes of faults in the operation of TR-7A scraper conveyor, as well as to estimate the necessary time for their remediation and identify the possibilities for their prevention and elimination. The practical data necessary for the above analyses were obtained for the TR-7A scraper conveyors equipped with mechanized complexes that operated on the long wall, on the $3^{\text {rd }}$ coal layer (in the Jiu Valley basin).

The paper presents the ways to recondition some surfaces of TR-7A conveyor subassemblies subjected to abrasion caused by deposition of successive layers of material with different properties, so that they can withstand high thermal and mechanical loads, while ensuring increased abrasion resistance.

The specific conditions in the underground environment (humidity, gas emissions) necessitate restoration of the technological equipment subassemblies suffering from the underground exploitation and using some materials with specific properties, usually antagonistic.

The materials from which these subassemblies are made of should possess certain physical-mechanical characteristics: high mechanical resistance (hardness and tenacity), resistance to abrasive wear; resistance to high temperatures; mechanical and thermal shock resistance.

At present, it is necessary to find materials and methods for reconditioning of spare parts and subassemblies subject to the most frequent failures in order to reduce production costs in coal mines [15].

\section{Materials and methods}

\subsection{TR-7A scraper conveyor}

TR-7A conveyors (Table 1) are part of the "heavy" (armored) machinery, and they differ from the "light" one, by playing a double role of transportation and travelling with another machine (mining shearer). The difference between the two constructions consists in their dimensions, mechanical resistance and manufacturing process of the troughs.

TR 7A conveyor (Fig. 1) can work with a cutting shearer with a weight of up to $400 \mathrm{kN}$ and can be used in mining equipped with individual or mechanized supports on a floor with specific resistance to the allowable minimum compression $50 \mathrm{~N} / \mathrm{cm}^{2}$ (with inclination between $+35^{\circ}$ and $-35^{\circ}$ ).

Table 1. Technical characteristics of TR 7A conveyor

\begin{tabular}{lcc}
\hline Transport capacity & $\mathrm{t} / \mathrm{h}$ & 450 \\
\hline Transport length & $\mathrm{m}$ & $60 ; 120$ \\
\hline Chain speed & $\mathrm{m} / \mathrm{s}$ & $0.7 ; 0.9$ \\
\hline Installed power & $\mathrm{kW}$ & $2 \times 125$ \\
\hline Supply voltage & $\mathrm{V}$ & 660 \\
\hline Number of chain branches & $\mathrm{pcs}$ & 2 \\
\hline Step scraper & $\mathrm{mm}$ & 920 \\
\hline Height of the trough & $\mathrm{mm}$ & 220 \\
\hline Total height & $\mathrm{mm}$ & 1210 \\
\hline Total width & $\mathrm{mm}$ & 3914 \\
\hline Total weight & $\mathrm{t}$ & 66 \\
\hline
\end{tabular}

At present TR-7A conveyor is used in excavation from the Jiu Valley as a component part of the CMA-2 mechanized complex, being compatible with KS-3M shearer. This type of conveyors has the advantages of reliability, low weight, and easy maintenance. They use spare parts common to those of the TR$7 \mathrm{G}$ conveyor (for gallery), and their operating time without major interventions correlates with the repair program and exploitation of the face sliced according to the operation plan. 


\subsection{Estimating probability of failure of TR-7A conveyor subassemblies according to the law of exponential distribution}

In conventional terms, the unique parameter of quality is represented by the capacity of a product to carry out the function for which it was designed. In the construction of machines, mining equipment and installations, this functionality, usually, expresses those parameters of quality that correspond to the requirements of standards, technical documentation or other normative documents.

A problem of special importance is to evaluate the quality and maintain it over time. A good quality mining equipment must be safe in operation and maintain its initial performance over time. In this sense, the main factors of quality are availability, reliability and maintainability [16]-[18].

Reliability of mining equipment is best described by keeping its performance stable over time, which is materialized, in the design phase, by the judicious choice of equipment architecture, materials and manufacturing process. Further, during the equipment execution and operation, the data and observations help to improve its performance. In this context, the theoretical distribution laws that can model the mechanical phenomena of failure and restoration of a product, can be expressed by the following functions: exponential, normal, lognormal and Weibull.

Maintenance is a concept of using feed-back from the machinery operation and reliable calculations to optimize maintenance strategies in given technical and economic conditions.

The methodology and analytical relations used for the calculation of the reliability and maintainability parameters of TR-7A conveyor parts prone to failures are given below:

1. Knowing the values of the operating time between failures $t_{i}$ of the component in their ascending order, the size of the interval $\Delta t$ and their number $k$ are calculated using the formula of Sturges:

$$
\Delta t=\frac{t_{\max }-t_{\min }}{1+3.322 \cdot \lg n},
$$

where:

$t_{\max }$ - maximum operating time between failures;

$t_{\text {min }}$ - minimum operating time between failures;

$n$ - number of observations.

2. Mean time between failures will be:

$M[t]=\frac{\sum_{i=1}^{n} t_{i}}{n}$.

3. Failure rate $\lambda$, relative frequency $f\left(t_{i}\right)$ and cumulative frequency $F_{c}\left(t_{i}\right)$ are calculated via the relations:

$$
\begin{aligned}
& \lambda=\frac{1}{M[t]} ; \\
& f\left(t_{i}\right)=\frac{n_{i}}{n} ; \\
& F_{c}\left(t_{i}\right)=\sum_{i=1}^{k} f\left(t_{i}\right) .
\end{aligned}
$$

4. Theoretical distribution function (probability of failure) $F\left(t_{i}\right)$, based on the law of exponential distribution has the form:

$$
F\left(t_{i}\right)=1-e^{-\lambda t_{i}} \text {. }
$$

5. The difference between cumulative frequency $F_{c}\left(t_{i}\right)$ and theoretical function $F\left(t_{i}\right)$ is expressed by the distance $d$ :

$$
d=\left|F_{c}\left(t_{i}\right)-F\left(t_{i}\right)\right| \text {. }
$$

6. The validation of the adopted theoretical distribution law is obtained with the help of the Kolmogorov concordance test, depending on the $d_{\max }$ value, according to the inequality:

$$
d_{\max }<\frac{1.36}{\sqrt{n}} .
$$

7. Reliability function is given by:

$$
R(t)=e^{-\lambda t}
$$

8. The statistical indicators of maintainability are the mean time to repair MTR and rate of repair $\mu$, given by the relationships:

$M T R=\frac{1}{n} \sum_{i=1}^{n} t_{r i}$

$\mu=\frac{1}{M T R}$

where:

$t_{r i}$ - time to repair.

9. The number of spare parts to be reserved so as to cover the needs of maintenance will be:

$$
N=\frac{T}{M[t]},
$$

where:

$$
T \text { - operating time. }
$$

Increasing the total operating time, either by increasing the MTBF time or by reducing the MTR time, is one of the main objectives of maintenance. At the same time, the maintenance and repair activities must be carried out with the lowest possible expenses and at the best quality level.

\section{Results and discussion}

\subsection{The results obtained in the reliability study of TR-7A conveyor}

TR-7A conveyor was also used in the constructive version of the gallery and in all sectors associated with the collector transport flows. The defects found (Fig. 2) on TR-7A conveyor are identical to those of the conveyors operating on the gallery (TR-7G), as shown in Table 2.

(a)

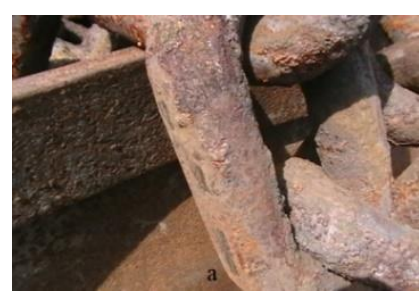

Figure 2. Used parts of TR-7A conveyor: (a) chain; (b) reduction gear (b)

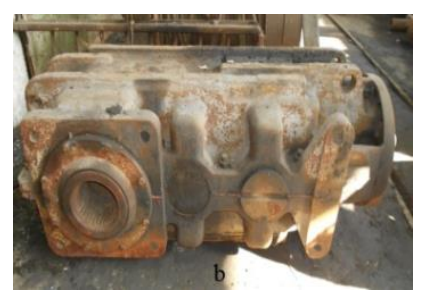
$x+\frac{1}{2}$ 
Table 2. TR-7A conveyor subassemblies with defects TR-7A conveyor

\begin{tabular}{|c|c|c|}
\hline Name & $\begin{array}{c}\text { During operation } \\
\text { between failures, hours }\end{array}$ & $\begin{array}{l}\text { Time to } \\
\text { repair, min }\end{array}$ \\
\hline 1. Chain & $\begin{array}{l}28 ; 126 ; 175 ; 322 ; 336 ; \\
343 ; 357 ; 378 ; 385 ; 756\end{array}$ & $\begin{array}{l}50 ; 60 ; 55 ; 60 ; 55 \\
65 ; 65 ; 45 ; 35 ; 40 ;\end{array}$ \\
\hline $\begin{array}{l}\text { 2. Electrical } \\
\text { defect }\end{array}$ & $\begin{array}{c}77 ; 84 ; 91 ; 105 ; 140 ; \\
147 ; 161 ; 161 ; 161 ; 168 ; \\
182 ; 182 ; 182 ; 184 ; 217 ; \\
238 ; 259 ; 259 ; 259 ; 427\end{array}$ & $\begin{array}{c}60 ; 50 ; 40 ; 65 ; 40 ; \\
40 ; 40 ; 35 ; 40 ; 40 ; \\
30 ; 45 ; 35 ; 35 ; 40 ; \\
\quad 45 ; 40 ; 35\end{array}$ \\
\hline 3. Switch PVI & $\begin{array}{c}112 ; 154 ; 182 ; 238 ; 280 \\
301 ; 329 ; 350 ; 448\end{array}$ & $\begin{array}{l}80 ; 70 ; 60 ; 70 ; 70 ; \\
60 ; 60 ; 05 ; 70 ; 55\end{array}$ \\
\hline $\begin{array}{l}\text { 4. Hydraulic } \\
\text { coupling }\end{array}$ & $\begin{array}{c}231 ; 371 ; 399 ; 427 ; 504 ; \\
525 ; 679\end{array}$ & $\begin{array}{c}90 ; 80 ; 80 ; 90 ; 95 ; \\
100 ; 85 \\
\end{array}$ \\
\hline 5. Chain lifter & $\begin{array}{c}98 ; 182 ; 287 ; 308 ; 371 ; \\
462 ; 581 ; 763\end{array}$ & $\begin{array}{c}100 ; 110 ; 110 \\
100 ; 110 ; 110 \\
95 ; 100 \\
\end{array}$ \\
\hline $\begin{array}{l}\text { 6. Reduction } \\
\text { gear }\end{array}$ & $\begin{array}{c}147 ; 182 ; 378 ; 427 ; 462 \\
497 ; 700\end{array}$ & $\begin{array}{c}140 ; 120 ; 120 ; \\
120 ; 120 ; 125 \\
125 ; 110\end{array}$ \\
\hline 7. Return drum & $370 ; 987 ; 1512$ & $130 ; 120 ; 105$ \\
\hline 8. Drum drive & $420 ; 504 ; 567 ; 1127$ & $\begin{array}{l}160 ; 140 \\
125 ; 130 \\
\end{array}$ \\
\hline 9. Electric motor & $399 ; 749 ; 1526$ & $150 ; 160 ; 160$ \\
\hline
\end{tabular}

The centralizer of the reliability indicators (Table 3 ) calculated on the basis of the data from Table 2 allowed to build the Pareto diagram (Fig. 3) which highlights the frequency of failure $f_{c}$ and the weight of repair time $p_{r}$ for the parts responsible for failures of TR-7A conveyor. Centralized results regarding the variation of reliability $R(t)$ depending on time for the TR7A conveyor parts responsible for failures, are given in Table 4 and presented graphically in Figure 4.

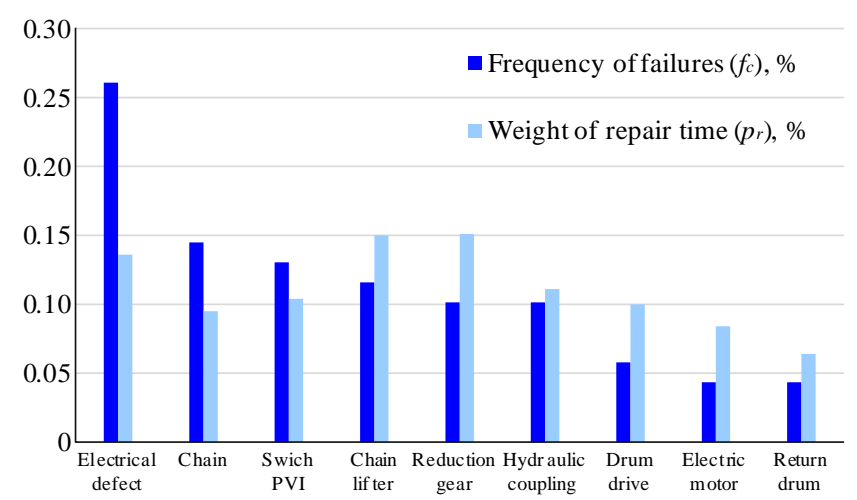

Figure 3. Pareto diagram for the parts that presented failures at the TR-7A conveyor

Table 3. Centralizer of the reliability and maintainability indicators for the parts responsible for failures of TR-7A conveyor

\begin{tabular}{|c|c|c|c|c|c|c|c|c|c|}
\hline No. & Name & $\begin{array}{c}\text { Number } \\
\text { of fai- } \\
\text { lures } n_{i}\end{array}$ & $\begin{array}{l}\text { Failures } \\
\text { frequency } \\
\quad f_{c}, \%\end{array}$ & $\begin{array}{l}\text { Time to } \\
\text { repair, } \\
\text { min }\end{array}$ & $\begin{array}{c}\text { Weight } \\
\text { of repair } \\
\text { time } p_{r}, \%\end{array}$ & $\begin{array}{c}\text { Mean } \\
\text { time to } \\
\text { repair } \\
\text { MTR, min }\end{array}$ & $\begin{array}{l}\text { Distribu- } \\
\text { tion law }\end{array}$ & $\begin{array}{c}\text { Reliability } \\
\text { parameters, } \\
\text { hour }^{-1}\end{array}$ & $\begin{array}{l}\text { Mean time } \\
\text { between } \\
\text { failures } \\
\text { MTBF, hour }\end{array}$ \\
\hline 1 & Chain & 10 & 0.1449 & 530 & 0.095 & 53.0 & Exp & $\lambda=0.0003119$ & 320.6 \\
\hline 2 & Electrical defect & 18 & 0.2608 & 755 & 0.136 & 41.9 & Exp & $\lambda=0.00537$ & 185.8 \\
\hline 3 & Switch PVI & 9 & 0.1304 & 580 & 0.104 & 64.4 & Exp & $\lambda=0.00375$ & 266.0 \\
\hline 4 & Hydraulic coupling & 7 & 0.1014 & 620 & 0.111 & 88.5 & Exp & $\lambda=0.00223$ & 448.0 \\
\hline 5 & Chain lifter & 8 & 0.1159 & 835 & 0.150 & 104.4 & Exp & $\lambda=0.00262$ & 381.5 \\
\hline 6 & Reduction gear & 7 & 0.1014 & 840 & 0.151 & 120.0 & Exp & $\lambda=0.0025$ & 399.0 \\
\hline 7 & Return drum & 3 & 0.0434 & 355 & 0.064 & 118.3 & Exp & $\lambda=0.0009$ & 1089.6 \\
\hline 8 & Drum drive & 4 & 0.0579 & 555 & 0.100 & 138.7 & Exp & $\lambda=0.00152$ & 654.5 \\
\hline \multirow[t]{2}{*}{9} & Electric motor & 3 & 0.0434 & 470 & 0.084 & 156.0 & Exp & $\lambda=0.00112$ & 891.3 \\
\hline & Total & 69 & & 5540 & & & & & \\
\hline
\end{tabular}

Table 4. Comparative values of reliability $R(t)$ as a function of time for the parts responsible for failures of TR-7A conveyor

\begin{tabular}{|c|c|c|c|c|c|c|c|c|c|c|c|}
\hline \multirow{3}{*}{ No. } & \multirow{3}{*}{ Name } & \multicolumn{10}{|c|}{ Reliability $R(t)$} \\
\hline & & \multicolumn{10}{|c|}{ Operation time $t$, in hours } \\
\hline & & 100 & 200 & 300 & 400 & 500 & 600 & 700 & 800 & 900 & 1000 \\
\hline 1 & Chain & 0.73 & 0.53 & 0.39 & 0.28 & 0.21 & 0.15 & 0.11 & 0.08 & 0.06 & 0.04 \\
\hline 2 & Electrical defect & 0.58 & 0.34 & 0.19 & 0.11 & 0.06 & 0.04 & 0.02 & 0.01 & 0.007 & 0.004 \\
\hline 3 & Switch PVI & 0.68 & 0.47 & 0.32 & 0.22 & 0.15 & 0.10 & 0.07 & 0.05 & 0.03 & 0.02 \\
\hline 4 & Hydraulic coupling & 0.80 & 0.64 & 0.51 & 0.41 & 0.32 & 0.26 & 0.21 & 0.16 & 0.13 & 0.10 \\
\hline 5 & Chain lifter & 0.77 & 0.59 & 0.45 & 0.35 & 0.27 & 0.20 & 0.16 & 0.12 & 0.09 & 0.07 \\
\hline 6 & Reduction gear & 0.778 & 0.60 & 0.47 & 0.36 & 0.28 & 0.22 & 0.17 & 0.13 & 0.10 & 0.08 \\
\hline 7 & Return drum & 0.91 & 0.83 & 0.76 & 0.69 & 0.63 & 0.58 & 0.53 & 0.48 & 0.44 & 0.40 \\
\hline 8 & Drum drive & 0.86 & 0.74 & 0.63 & 0.54 & 0.46 & 0.40 & 0.35 & 0.29 & 0.25 & 0.22 \\
\hline 9 & Electric motor & 0.89 & 0.79 & 0.71 & 0.63 & 0.57 & 0.51 & 0.45 & 0.40 & 0.36 & 0.32 \\
\hline
\end{tabular}

Chain and electrical defects are related to high frequencies of failure and require frequent replacements, while reduction gears (gears and shafts) and chain lifters most often require reconditioning. Using relation (12), it was possible to calculate the required number of spare parts, especially for the components with the lowest reliability, namely: chain (10 pieces), switch PVI (9 pieces), chain lifter (8 pieces) and reduction gear ( 7 pieces).

\subsection{Possibilities for reconditioning some parts of TR-7A conveyor}

Improved reliability of subassemblies of mining technological equipment contributes to the increase in its productivity and efficiency. The complex of properties required in the operating conditions can be offered by the composite or plated materials, which are structurally gradient and implicitly functional. 


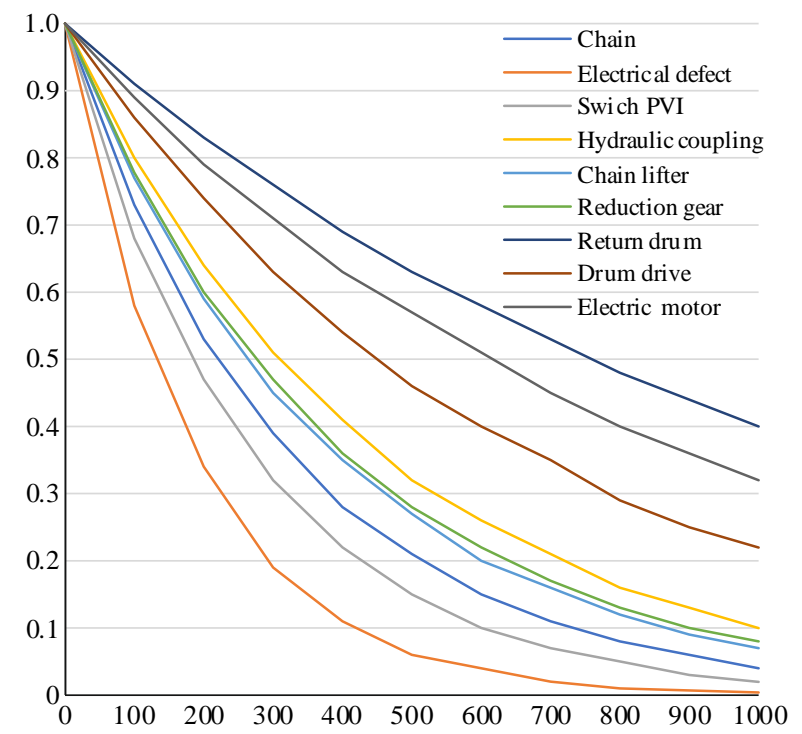

Figure 4. Reliability variation $R(t)$ for the parts responsible for failures of TR-7A conveyor

Such materials, designed to have a set of properties, sometimes antagonistic, are defined as FGM (Functional Gradient Materials). Composite materials comprise a special category, in which the emphasis is both on the differences in the chemical composition of the phases (which make up the material) and on how these phases appear in the structure (powders, long or short fibers etc.) and can meet certain functional requirements. Some of them are currently manufactured with technology that produces the change of properties during their processing.

Materials with compositional and functional gradient can be created by melting, static casting, infiltration or welding.

At Lupeni mining unit, the abrasion-worn surfaces of the chain lifter were reconditioned to obtain a multilayer structure by electric welding with tungsten carbide powder electrodes.

Experiments in reconditioning of the chain lifter required numerous attempts to achieve the optimal share of the additive material and the appropriate coefficients of the alloying elements passage into the deposited layer.

The adhesion between the layers (Fig. 5) was good and a proper homogenization of the deposited material was obtained.

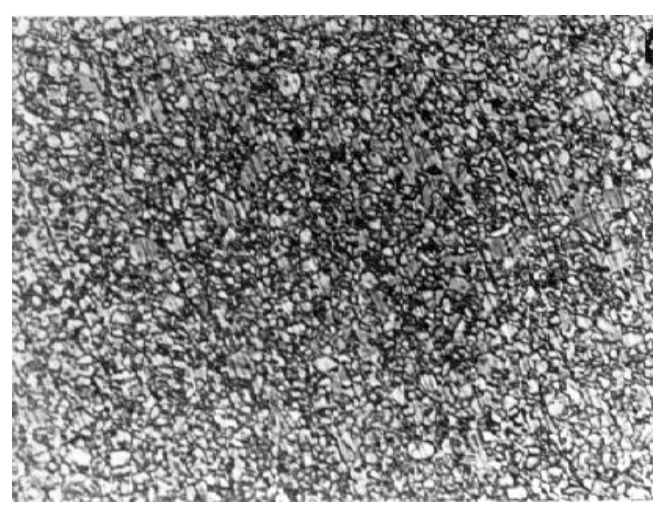

Figure 5. Material microstructure interface of the reconditioned chain lifter

The reconditioned chain lifters were tested in operation, with an increase in MTBF from 381.5 to 502 hours, which confirms that hard alloy coating of abrasion-worn surfaces is an adequate solution and can be applied in the maintenance of mine equipment.

\section{Conclusions}

Continuous operation of mining equipment subassemblies, in general, and of scraper conveyors, in particular, is influenced by the working conditions, such as shocks, high vibrations and high humidity.

The solution proposed and experimentally tested at Lupeni mine for the subassemblies of mining equipment subjected to wear is to use welding to create surfaces with multilayer architecture, which would allow to improve their reliability indicators and contribute to the reduction of operating costs.

The advantages of electric arc welding and tungsten carbide powder electrodes are manifested in: high deposition productivity ensured by the new generation of electrodes (with high concentration of cobalt binders); easy accessibility to welding equipment; wide range of adjustments of the deposits wear resistance characteristics (by welding parameters).

Optimization of the deposits alloying level in pre-established conditions based on the criterion of the maximum wear resistance requires the preliminary study of the wear resistance variation depending on the alloying level. The theoretical results and recommendations on the electrodes for welding must be validated in production conditions, from the point of view of welding behaviour and the wear resistance. In the process of reconditioning, recovered electrodes with tungsten carbide powders can be used, which allows to reduce maintenance costs of mining equipment.

\section{Acknowledgements}

This work has been carried out without any funding from a grant or scientific project.

\section{References}

[1] Qu, D.R., Qiao, T.Z., Pang, Y.S., Yang, Y., \& Zhang, H.T. (2021). Research on ADCN method for damage detection of mining conveyor belt. IEEE Sensors Journal, 21(6), 8662-8669.

[2] Yang, X.W., Chen, H.Y., Mao, J., \& Wei, Y.J. (2020). Dynamical behavior of coal shearer traction-swing coupling under corrected loads. Scientific Reports, 10(1), 8630. https://doi.org/10.1038/s41598-020-65184-W

[3] Morshedlou, A., Dehghani, H., \& Hoseinie, S.H. (2019). A data driven decision making approach for long-wall mining production enhancement Mining Science, (26), 7-20. https://doi.org/10.37190/msc192601

[4] Jiang, S.B., Zeng, Q.L., Wang, G., Gao, K.D., Wang, Q.Y., \& Hidenori, K. (2018). Contact analysis of chain drive in scraper conveyor based on dynamic meshing properties. International Journal of Simulation Modelling, 17(1), 81-91. https://doi.org/10.2507/ijsimm17(1)418

[5] Tomus, O.B., Andras, A., \& Magyari M. (2017). Study on the reliability of the underground conveyor belt system installed at Vulcan Mine, the Jiu Valley Basin in Romania. MATEC Web of Conferences, (121), 01016. https://doi.org/10.1051/matecconf/201712101016

[6] Pana, L., Grabara, J., Pasculescu, D., Pasculescu, V.M., \& Moraru, R.I (2018). Optimal quality management algorithm for assessing the usage capacity level of mining transformers. Polish Journal of Management Studies, 18(2), 233-244. https://doi.org/10.17512/pjms.2018.18.2.19

[7] Pasculescu, V.M., Vlasin, N.I., Florea, D., \& Suvar, M.C. (2017). Improving the quality of the process for selecting electrical equipment intended to be used in potentially explosive atmospheres. Quality - Access to Success, 18(S1), 97-102.

[8] Pasculescu, V.M., Pricop, D.G., Morar, M.S., \& Florea V.A. (2015). Research on the development of an expert system for selecting technical equipment intended to be used in potentially explosive atmospheres. International Multidisciplinary Scientific GeoConference-SGEM, Exploration and Mining, (I), 291-298. https://doi.org/10.5593/SGEM2015/B21/S7.036

[9] Florea, V.A., \& Loga, W. (2013). Posibilities to increase the operating safety and the reliability of mining technological equipments. International Multidisciplinary Scientific GeoConference-SGEM, Exploration and Mining, (I), 579-586. https://doi.org/10.5593/SGEM2013/BA1.V1/S03.047

[10] Florea, V.A. (2016). Reliability analysis equipment for cutting and transportation in case of a mining flux technology. International 
Multidisciplinary Scientific GeoConference-SGEM, Exploration and Mining, (II), 719-725. https://doi.org/10.5593/SGEM2016/B12/S03.094

[11]Lozynskyi, V., Medianyk, V., Saik, P., Rysbekov, K., \& Demydov, M. (2020). Multivariance solutions for designing new levels of coal mines. Rudarsko Geolosko Naftni Zbornik, 35(2), 23-32. https://doi.org/10.17794/rgn.2020.2.3

[12] Petlovanyi, M., Lozynskyi, V., Zubko, S., Saik, P., \& Sai, K. (2019). The influence of geology and ore deposit occurrence conditions on dilution indicators of extracted reserves. Rudarsko Geolosko Naftni Zbornik, 34(1), 83-91. https://doi.org/10.17794/rgn.2019.1.8

[13] Mustafin, S.A., Duisen, G.M., Zeinullin, A.A., \& Korobova, E.V. (2019). Evaluation of the choice of borrower rating groups. News of the National Academy of Sciences of the Republic of Kazakhstan, 6(438). https://doi.org/10.32014/2019.2518-170X.166

[14] Beshta, O.S. (2012). Electric drives adjustment for improvement of energy efficiency of technological processes. Naukovyi Visnyk Natsionalnoho Hirnychoho Universytetu, (4), 98-107.
[15] Wang, X., Yang, J., Quan, L., Zhang, K., \& Wang, J. (2018). A novel highefficiency wheel loader power steering system with fault-tolerant capability. IEEE Transactions on Vehicular Technology, 67(10), 9273-9283. https://doi.org/10.1109/TVT.2018.2856933

[16] Bajda, M., Błażej, R., \& Jurdziak, L. (2019). Analysis of changes in the length of belt sections and the number of splices in the belt loops on conveyors in an underground mine. Engineering Failure Analysis, (101), 436446. https://doi.org/10.1016/j.engfailanal.2019.04.003

[17] Niculescu, T., Pasculescu, D., Pasculescu, V.M., \& Stoica, I.O. (2014). Evaluation of electrical parameters of intrinsic safety barriers of the electrical equipment intended to be used in atmospheres with explosion hazard. International Multidisciplinary Scientific GeoConference Surveying Geology and Mining Ecology Management, 1(2), 169-176. https://doi.org/10.5593/SGEM2014/B21/S7.022

[18] Popescu, F.G., Pasculescu, D., Marcu, M.D., \& Pasculescu, V.M. (2020). Analysis of current and voltage harmonics introduced by the drive systems of a bucket wheel excavator. Mining of Mineral Deposits, 14(4), 40-46. https://doi.org/10.33271/mining14.04.040

\section{Надійність та експлуатаційні якості скребкового конвеєра, що використовується при видобутку вугілля в долині Джиу}

\section{В.А. Флореа, Д. Паскулеску, В.М. Паскулеску}

Мета. Визначення та аналіз причин несправностей у роботі скребкового конвеєра, оцінка часу їх усунення та вибір методів їх запобігання й ліквідації при видобутку вугілля.

Методика. Скребковий конвеєр ТР-7А, який призначений для виконання заданої функції у часі та в певних умовах експлуатації був теоретично вивчено шляхом визначення його експлуатаційної надійності. Це має на увазі наявність структури, яка включає кілька взаємопов'язаних компонентів технічного, експлуатаційного, комерційного та управлінського характеру. Кількісне вираження надійності засноване на елементах математичної теорії ймовірностей і статистики (експоненціального закону розподілу); з урахуванням того, що механізм поломки і ремонту обладнання не підпорядковується певним законам.

Результати. Визначено вузли конвеєра TR-7А, які в разі несправності, можуть бути причиною відмови в роботі: ланцюги, гідравлічні муфти, ланцюгові підйомники, привід, поворотні барабани, деякий електричне обладнання. Після 28 місяців моніторингу роботи TR-7А було визначено кількість поломок (несправностей) $n_{i}$, робочий час між поломками $t_{i}$, частота поломок $f_{c}$, час ремонту $t_{r i}$, вагова частка часу ремонту $p_{r}$, середній час між поломками (MTBF), середній час ремонту (MTR).

Наукова новизна. Встановлено коректні причини і частота збоїв у роботі скребкових конвеєрів на основі нового підходу збору та обробки експериментальних даних. Реалізація даного підходу дозволила знайти рішення для підвищення надійності деяких вузлів конвеєра ТР-7А, схильних до абразивного зносу.

Практична значимість. Одним з рішень було використання матеріалів з композиційним і функціональним градієнтом для відновлення зношених поверхонь деяких вузлів. Цей підхід був успішно застосований для ланцюгових підйомників, в результаті чого середній час між поломками значно збільшився. Такі матеріали можуть застосовуватися для відновлення металевих вузлів машин і устаткування, схильних до абразивного зносу як при підземній, так і відкритій розробці родовищ.

Ключові слова: конвеєр, видобуток вугілля, експонентний закон розподілу, багатошарова структура, ремонт, надійність, знос

\section{Надежность и эксплуатационные качества скребкового конвейера, используемого при добыче угля в долине Джиу}

\section{В.А. Флореа, Д. Паскулеску, В.М. Паскулеску}

Цель. Определение и анализ причин неисправностей в работе скребкового конвейера, оценка времени их устранения и выбор методов их предотвращения и ликвидации при добыче угля.

Методика. Скребковый конвейер ТР-7А, который предназначен для выполнения заданной функции во времени и в определенных условиях эксплуатации, был теоретически изучен путем определения его эксплуатационной надежности. Это подразумевает наличие структуры, которая включает несколько взаимосвязанных компонентов технического, эксплуатационного, коммерческого и управленческого характера. Количественное выражение надежности основано на элементах математической теории вероятностей и статистики (экспоненциального закона распределения); с учетом того, что механизм поломки и ремонта оборудования не подчиняется определенным законам.

Результаты. Определены узлы конвейера TR-7A, которые в случае неисправности, могут быть причиной отказа в работе: цепи, гидравлические муфты, цепные подъемники, привод, возвратные барабаны, некоторое электрическое оборудование. После 28 месяцев мониторинга работы TR-7А было определено количество поломок (неисправностей) $n_{i}$, рабочее время между поломками $t_{i}$, частота поломок $f_{c}$, время ремонта $t_{r}$, весовая доля времени ремонта $p_{r}$, среднее время между поломками (MTBF), среднее время ремонта (MTR).

Научная новизна. Установлены корректные причины и частота сбоев в работе скребковых конвейеров на основе нового подхода сбора и обработки экспериментальных данных. Реализация данного подхода позволила найти решения для повышения надежности некоторых узлов конвейера ТР-7А, подверженных абразивному износу.

Практическая значимость. Одним из решений было использование материалов с композиционным и функциональным градиентом для восстановления изношенных поверхностей некоторых узлов. Этот подход был успешно применен для цепных подъемников, в результате чего среднее время между поломками значительно увеличилось. Такие материалы могут применяться для восстановления металлических узлов машин и оборудования, подверженных абразивному износу как при подземной, так и открытой разработке месторождений.

Ключевые слова: конвейер, добыча угля, экспоненциальный закон распределения, многослойная структура, ремонт, надежность, износ 